\title{
Tessellation Planning: Relationships between the physical environment and the neighbourhood
}

\author{
Anniz Fazli Ibrahim Bajunid, Mohamed Yusoff Abbas, Abdul Hadi Nawawi \\ cE-Bs, Faculty of Architecture, Planning and Surveying \\ Universiti Teknologi MARA, Malaysia \\ toanniz@gmail.com
}

\begin{abstract}
The fundamental objective of the national housing agenda is to ensure a better quality of life. The challenge is to develop affordable houses whilst sustaining positive social neighbourhoods. In the western world, research equated the physical environment as a dominant influence on the spatial behaviours of communities. Quality of living in Malaysia is only obtainable to the upper echelons in organic planning of housing. These perceived as successful neighbourhoods such as the cul-de-sac or Tessellation Planning create a relationship between the physical environment and the neighbourhood. This paper initiates a search for such literature and identifies key concepts for further deliberations.
\end{abstract}

Keywords: tessellation planning, cluster layouts, culs-de-sac, quality of life

eISSN 2514-751X @ 2017 The Authors. Published for AMER ABRA by e-International Publishing House, Ltd., UK. This is an open-access article under the CC BY-NC-ND license (http://creativecommons.org/licenses/by-ncnd/4.0/). Peer-review under responsibility of AMER (Association of Malaysian Environment-Behaviour Researchers), ABRA (Association of Behavioural Researchers on Asians) and CE-Bs (Centre for EnvironmentBehaviour Studies), Faculty of Architecture, Planning \& Surveying, Universiti Teknologi MARA, Malaysia.

https://doi.org/10.21834/aje-bs.v2i5.225 


\subsection{Introduction}

The literature of Environment-Behaviour in the area of research is vast amongst researchers in developed nations. Appropriately, Environment-Behaviour (EB) studies, especially within the built environment, are only beginning to take interest in Malaysia. Social scientists of developed nations have throughout the decades investigated relationships of the urban realm onto that of communities. In particular, the continuous debate has focused on new urbanism and its physical provisions in the finer grain of neighbourhoods and its implications on the larger community. Recent literature include works of Mason (2010), Hipp (2010), Lovejoy, Handy \& Mokhtarian (2010) and Lawhon (2009), as interest grows within the trans- disciplinary field of environment-behaviour. The culs-de-sac, among many design planning layout initiatives are among a planning practice that is constantly disputed upon. Early literature of these discussions includes Jane Jacobs's, 'Life and Death of Great American Cities' in 1961 and Mayo's, 'Effects of Street Forms on Suburban Neighboring Behavior' in 1979. The studies of Mohit, Ibrahim \& Rashid (2010), Zakaria and Yang (2004), Nurizan (1993) are among the few Malaysian researchers examining neighbourhoods (lowcost housing) and quality of life. Such academic debates are rather limited in Malaysian literature of the built environment.

In a typical architectural design practice, neighbourhood planning begins typically by zoning and subdivision of land according to different classifications and local statutory requirements. It is a dominant planning strategy in the implementation of mass housing policies in Malaysia for planners and developers alike. The design of the curvilinear layout or the organic cul-de-sac is often regarded and perceived as the pinnacle of a development, with the allocations of loftier housing units with specific intention of creating appealing communities and better quality of life. This paper seeks through a broad literature search, only to identify specific key concepts of the relationships between the physical environment and neighbourhood quality of life within the design layout settings of a Malaysian cul-de-sac neighbourhood. The paper initiates a discussion whether this layout is ideal and debates for a more effective planning method, especially within the context of mass housing policies in the Malaysian multicultural domain.

The paper shall be divided into three segments; first, the process of how the broad search of literature was exhaustively initiated and conducted; second, the initial key concepts deliberated by the literature reviewed; and thirdly, preliminary discussions leading from the key concepts to the need of further research and recommendations.

\subsection{Literature Review}

\subsection{Literature Sourcing}

Understanding the relationships of neighbourhoods within their built environment context 
transgresses multiple disciplines. This relationship is apparent if one were to just Google physical environment and neighbourhoods, whereby there exist almost 4 million different materials offering diverse perspectives. The paper limits the scope in specific to only a cul-desac neighbourhood within the context of Malaysia. However, in order to better understand a complete picture of its relationships, a thorough search of initial scholarly literature that frames the periphery of the diverse disciplines, was undertaken.

\subsection{Databases Accessed}

As Universiti Teknologi MARAstrives to achieve its aspiration as the leading university in Malaysia, there has been a momentous thrust in the development of academic sourcing via online journals. Within the sphere of reputable journals databases (Figure 1), UiTM's libraries hold in their collection amongst the largest databases in the country (Bajunid, 2011b). There are of course a number of databases still in their wish list that is currently under review for comprehensive subscription such as the Environment and Behaviour Journal, which will become available in a matter of weeks, upon the writing of this paper. The need for a comprehensive database is self-evident as UiTM has one of the largest number of students within a myriad of an extensive number of programmes in 23 different faculties in all the states in Malaysia (Bajunid, 2011a). This paper uses the availability of the 74 databases within 23 academic domains based on keywords pertaining to the topic of study. Among the academic databases used included SAGE Premiere Journals Online, WizFolio's Scholars Portal, SciVerse Hub (Beta) consisting of Scopus and Science Direct journal search engines. Most importantly, UiTM's Serial Solutions: 360 Link and Search, encapsulates all the above databases in an entirety, in a one-stop database of all the 74 databases available currently. Apart from private academic portals, public accesses of the Google Search engine and Google Scholar was also used extensively for the purpose of this study.

\subsection{Refining documentation identification}

Documents were first identified through specific keywords. This process is then continued with further advanced search with a chain of keywords administering the Boolean logic (Cohen, 2011). Research domains were then identified by abstracts and searched in specific and in full within the databases. The most relevant keywords strings were given priority. By setting daily alerts accounts via email journals of SAGE Premiere, Google Scholar, Scopus and Science Direct, and the availability of the Scopus and Science Direct on an iPhone App, this alert process was further enhanced by the hour. It was also ensured that although UiTM's Serial Solution one stop search engine was available, all relevant major databases mentioned above were additionally searched independently to ensure the rigorousness and reliability of the sourcing. All technical troubleshooting was easily available via direct email communication with relevant vendors. 
Bajunid, A.F. I., et.al. / Asian Journal of Environmen-Behaviour Studies, ajE-Bs, 2(5) Oct / Dec 2017 (p.85-95)

\begin{tabular}{|c|c|c|c|}
\hline ACM Digital Library & $\begin{array}{l}\text { EBSCO : Econlit with } \\
\text { Ful Text }\end{array}$ & $\begin{array}{l}\text { Imtemational Index to } \\
\text { Music Periodicals }\end{array}$ & ProQuest Education \\
\hline $\begin{array}{l}\text { American Chemical } \\
\text { Society (ACS) }\end{array}$ & EBSCO : DynaMed & $\begin{array}{l}\text { Intemational index to } \\
\text { Perlorming Aits }\end{array}$ & Springer Protocel \\
\hline $\begin{array}{l}\text { American society of Civil } \\
\text { Engineers (ASCE) }\end{array}$ & $\begin{array}{l}\text { EBSCO : Scientific \& } \\
\text { Medical ART Imagebase }\end{array}$ & IOP science & SAGE Premier \\
\hline $\begin{array}{l}\text { American Society of } \\
\text { Clinical Oncelogy (ASCO) }\end{array}$ & $\begin{array}{l}\text { EBSCO : MEDLINE with } \\
\text { Ful Text }\end{array}$ & Is! Web ot Knowledge & Science Direct \\
\hline $\begin{array}{l}\text { American Society of } \\
\text { Mechanical Engineers } \\
\text { (ASME) }\end{array}$ & $\begin{array}{l}\text { EBSCO : CINAHL with } \\
\text { Ful Tex }\end{array}$ & ITS Mare & Science Direct Backdile \\
\hline Anasomyst & $\begin{array}{l}\text { Emerald Bacufies (" Eanly } \\
\text { Onine Database Access) }\end{array}$ & Karger & Scifinder Scholar \\
\hline $\begin{array}{l}\text { ASTM Standards and } \\
\text { Engineering Digtas Library }\end{array}$ & Emerald Management Plus & Kinetidex & Scopus \\
\hline Banksecope & $\begin{array}{l}\text { Global Markes Infomation } \\
\text { Database (GMD) }\end{array}$ & Lawivet & $\begin{array}{l}\text { Serial Solutions: } \\
360 \text { Link }\end{array}$ \\
\hline BMJ Best Practice & $\begin{array}{l}\text { Hein Online Invemational } \\
\text { Core Colection ("."Eary } \\
\text { Onine Database Access) }\end{array}$ & LC Web Classification & $\begin{array}{l}\text { Serial Solutions : } \\
360 \text { search }\end{array}$ \\
\hline BMJ Joumals & $\begin{array}{l}\text { Health \& Wellness } \\
\text { Resource Centre }\end{array}$ & $\begin{array}{l}\text { Lexis Nexis.com } \\
\text { (Legal Research) }\end{array}$ & Springer LINK \\
\hline $\begin{array}{l}\text { BLIS (Bernama Library } \\
\text { Infolink Service) }\end{array}$ & $\begin{array}{l}\text { H w wilsen Omni File } \\
\text { Full Text }\end{array}$ & $\begin{array}{l}\text { Lexis Nexis eAcademic } \\
\text { Universe }\end{array}$ & $\begin{array}{l}\text { Proquest Digital } \\
\text { Dissertation \& Thesis }\end{array}$ \\
\hline $\begin{array}{l}\text { British Standard Online } \\
\text { (BS Online) }\end{array}$ & $\begin{array}{l}\text { High Wire Osen Colection: } \\
\text { Molecular Pharmacology }\end{array}$ & $\begin{array}{l}\text { Lippincott. Wilam s } \\
\text { Wilivins (access via } \\
\text { Ovid database) }\end{array}$ & $\begin{array}{l}\text { Taylor \& Francis } \\
\text { (Geography Archives) }\end{array}$ \\
\hline Compendex & $\begin{array}{l}\text { Drug Netabolism a } \\
\text { Disposition }\end{array}$ & Malaysian Legal Alert & $\begin{array}{l}\text { Thomson One Barker } \\
\text { (Worloscope) }\end{array}$ \\
\hline CLULaW & $\begin{array}{l}\text { The Journal of Pharmaology } \\
\text { \&. Experimental Therapeusica }\end{array}$ & $\begin{array}{l}\text { Malaysian Standards } \\
\text { Online (OAS Onine) }\end{array}$ & Uirich's Wes \\
\hline Datastream & Pharmacological Reviews & Marindale & Westiaw \\
\hline Drugdex System & Melecular interventions & MD Consus: & Wiey Online Library \\
\hline $\begin{array}{l}\text { EBsco: Academic } \\
\text { Source Premier }\end{array}$ & IEEE Explore & Osiris & WizFolo \\
\hline $\begin{array}{l}\text { EBSCO : Business } \\
\text { Source Complete }\end{array}$ & Islamic Finance news (IFN) & $\begin{array}{l}\text { Oxford Joumals: } \\
\text { Human Reproduction }\end{array}$ & $\begin{array}{l}\text { Proquest ABV } \\
\text { INFORM Complete }\end{array}$ \\
\hline $\begin{array}{l}\text { EBSCO : Dentistry \& } \\
\text { Oral Sciences }\end{array}$ & $\begin{array}{l}\text { Indian Journals.cem - } \\
45 \text { titles Apricusure }\end{array}$ & $\begin{array}{l}\text { Ovid Fut: Text Colections: } \\
\text { Jounals Govid }\end{array}$ & IET inspec Direct \\
\hline
\end{tabular}

Figure 1: UiTM's online database continuing expansion and comprehensive coverage. Databases in direct connection to the built environment (identified by UiTM) and of higher relevance to the research have been highlighted.

(Source: Adapted from UiTM's Online Database. Available at http://library.uitm.edu.my/v1.0/ eresources/S.html.) 


\subsection{Extensiveness}

Upon initial search, it was observed that the research extends through multiple disciplines. Due to limited resources, a preliminary adapted systematic review was undertaken to ascertain the extensiveness of the data sourcing within that capacity. This adaptation in this paper only highlights a preliminary synthesis of the sourcing narratively, identifying key concepts with limited graphical displays. A flow diagram disclosing the review sourcing process is as shown in Figure 2 conducted during a span of three months in early 2011. The volumes of data are a reflection of available materials during that time span as more materials continue to be constantly uploaded.

Overlapping of articles within search databases highlights their availability to researchers. Citations identified by others were also a criterion for selection but will not be displayed in this paper. These selection criteria was reduced to domain identification and then further reduced to less than 200 entities (or less) within each domain according to relevancy. These articles were then manually assessed based on title, keywords and abstracts before being reviewed for key concepts.

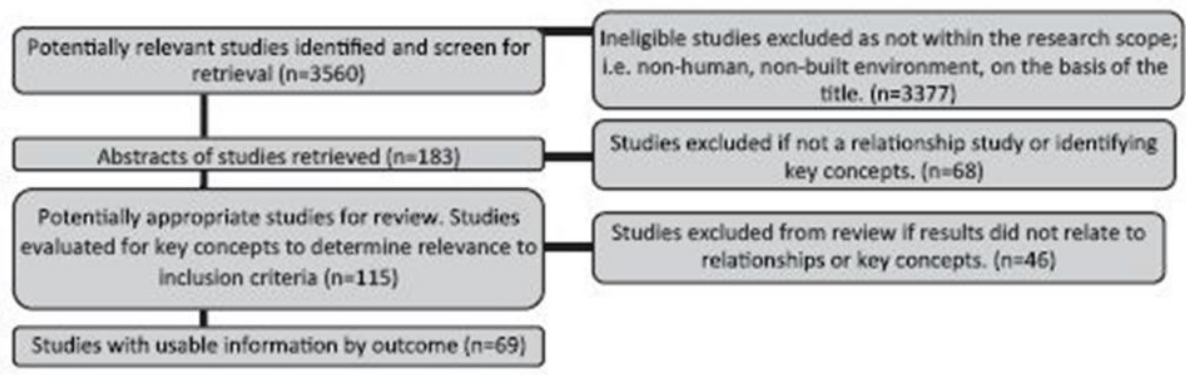

Figure 2: Illustration of the flow diagram screening process for relevancy before being reviewed for key concepts

(Source: Adaptation from a QUOROM 1999, Quality of Reporting of Meta-analyses / CONSORT 2010, Consolidated Standards of Reporting Trials flowchart. (Moher, et al., 2010; Petticrew \& Roberts, 2006; Schulz, Altman, \& Moher, 2010)

\subsection{Multi-disciplines of sourced literature}

Initial search on published literature on relationships between the physical environments and neighbourhoods' quality of life, is relatively scarce within the Malaysian context. Internationally however, this subject continues to expand its literature and scope with the advent of technological advancement of the built environment and the continuous sociological change of communities. This was reflected in the myriad of disciplines found contributing to the discussion during the conduct of the literature search. The listing of all different journals' domain identified shall not be discussed explicitly in this paper. 


\subsection{Discussions}

The diverse disciplines had in common several issues of interest. These interests are the key concepts the paper set out to bring forward. These concepts are a summary of researches from diverse studies about the understanding of the broad relationships of the physical environment and neighbourhoods. This paper initiates a discussion of some of these relationships, within the setting of the Malaysian cul-de-sac neighbourhoods and quality of life.

\subsection{The Cul-de-sac}

It is interesting to note that apart from two dominant recent studies by Cozens (2008) and Charmes (2010), many other articles on the cul-de-sac appear sporadic and were basically on the peripheral discussions of the topic. One of the articles prompted a study on trust in relation to community design factors. Within the smaller scope of the cul-de-sac, the study found that streets designed in a cul-de- sac (among other design elements) increases trust among residents and suggests that neighbourhood design carefully planned, is instrumental in the creation of quality of life (Mason, 2010). In another detailed study, Pendola and Gen (2008) highlighted the neighbourhood cul-de-sac in his literature by identifying a study by Brown and Werner in 1985, that "found high levels of 'neighbouring' in a study of residents of cul-de-sacs" and "inhabitants of a building with a courtyard over (greater sense of community among residents) those of one with an interior corridor" with a study conducted by Julian in 1995. There were some studies conducted by a highly cited researcher that propagated the new urbanism studies of street patterns in the United States, but most of the studies were in the 90's (Southworth and Ben-Joseph, 1995; 1997; Southworth and Owen 1993) but laid some foundation of the scenario of cul-de-sac. In the local setting, Hashim (2005) described housinglayouts that promotes a neighbourly atmosphere and one that builds relationships (a cul-de-sac type of planning). Othman (2010) in a study of cul-de-sacs and play spaces with children found that the children observed, were more socially active as well. Another claim in theory placed the cul-de-sac planning as a better layout than compared to its counter-part, the grid-iron. This theory is still awaiting verification as the prototypical cul-de-sac is under construction (Bajunid \& Ibrahim, 2007; Ghazali \& Bajunid, 2011).

\subsection{The neighbourhood unit}

The principles behind the 'neighbourhood unit' evolved through Perry's personal experiences as well as associations with prominent community design individuals of the 1920's such as Raymond Unwin and his involvement in the Garden City Movement (Lawhon, 2009). Identifying the success of a neighbourhood has been addressed in numerous studies, among which the critical factor is determined by the satisfaction level of its residents. A sub-sample study by Hipp (2010), measured structural characteristics of micro-neighbourhoods from the American Housing Survey of 1985, 1989 and 1993. His report suggests that higher neighbourhood satisfaction is found in the micro-neighbourhood 
level and in residential stability rather than in large samples, thus encouraging small neighbourhood units. A satisfaction study of eight neighbourhoods in California identified that attractive appearance and perceived safety on neighbourhoods were the most desired criteria in both suburban and traditional neighbourhoods (Lovejoy, Handy \& Mokhtarian, 2010). The cul-de-sac planning has an inherited value of safety and attractiveness. The measurement of a neighbourhood social environment was studied in detail in an adapted neighbourhood Quality of Life Study which categorized specifically social interaction, sense of community, informal social control and social cohesion as the key attributes of neighbourhoods (du Toit, Cerin, Leslie \& Owen, 2007). A vast number of satisfaction studies has been carried out in the United States with the advent of New Urbanism but have been adopted internationally as well, as in the case of Machi, a progressive historical adaptation of Perry's neighbourhood unit translated in modern Japan city planning (Hein, 2008). This, along some other scarce international articles has indicated that the study of the topic is still elusive but universal. It is prudent that local context scenario is sufficiently addressed, as in a study conducted by (Mohit, Ibrahim, \& Rashid, 2010) with the satisfaction of residents in public low-cost housing in Kuala Lumpur. In that particular study, forty-five variables have been identified and clustered into components. This seemed to be one of the latest empirical contributions in the local scenario that is available for further deliberation.

\subsection{About housing quality of life}

There seems to be a growing interest in the broader local scenario of 'quality of life'. This is true as the government drives towards achieving a developed nation status by 2020 (Aziz, 2002; Majid, 2010). In a report in 2002, Aziz's (2002) opinion survey of quality of life among 62 registered planners working in the Klang Valley concluded that planners considered six issues in their daily tasks. The issues seemed too generic to form any substantiated guidelines for planners when designing neighbourhoods. Ten years later, the Malaysian Quality of Life Index (MQLI) indicated that the Housing index improved from 19.2 to 33.5 from year 2000 to 2008 (Majid, 2010). However, this reflection was an overall improvement of the supply and provisions of the housing industry in the country, but whether the quality of living within the housing neighbourhoods has increased is arguable and inconclusive. It would be apparent if one were to drive and walk in a high-density lowcost neighbourhood in Malaysia, the living conditions state of affair is questionable. Limited research is currently available but on the rise, such as the works of Aziz \& Ahmad, 2009 on home making in low-cost housing areas.

\subsection{About children, health and transportation in a neighbourhood}

Children's social developments within a neighbourhood or community have been heavily documented overseas. The influence of the physical environment towards adolescent development has meticulously been recorded in a literature review by Murry, et al. in 2011. The researchers in particular, highlighted neighbourhood poverty and its impact on child 
development. Veitch, Salmon and Ball (2010), on the other hand observed the children's active free-play and the correlation of that to the physical environment. Among the many studies found, there was just one research which made a passing comment that a child who played and lived in a cul-de-sac was positively associated with and encourages children's active-play. There was however, limited further empirical research of the relationship of the cul-de-sac. There were also a number of papers which studied the walkability and health associated with children in neighbourhoods. There is a growing concern with adolescent obesity or other health related diseases. There are also contrary debates between the use of cars and buses rather than walking to schools due to street patterns and neighbourhood planning. The relationship of neighbourhoods in the context of safety and crime expanded further into another discipline, emphasizing the need of a trans-disciplinary research to more effectively assess the relationships of the physical environment to that of children's physical activity in a neighbourhood, as suggested by Davison and Lawson (2006).

\subsection{Conclusions}

It is reasonable to conclude that there are some preliminary key concepts and indicators suggesting a relationship between the physical environments of a cul-de-sac neighbourhood and quality of life of a community. However, further literature and research needs to be conducted across disciplines (trans-disciplinary) to be able to substantiate any form of robust conclusion as discerned by Hashim (2005). Until now, there seems to be a gap of understanding as to what actual attributes are involved in a cul-de-sac planning that may or may not contribute further to the quality of life of families within a neighbourhood. Identifying this phenomenon empirically shall contribute enormously to the corpus knowledge of architects, planners and developers alike and to the enhancement of the current MQL Index, especially as mass housing is currently dominantly implemented in gridiron modules.

In retrospective, the asserted prototypical Tessellation Planning was not discussed in this paper. However, the fundamentals that it advocates is on the effective cul-de-sac design planning method. This paper has been deliberated sensibly that the fundamental understanding of relationships needs to be identified first, before assessing a prototypical concept. Though not far from a possible post-occupancy evaluation study (POE), as a number of its projects are currently under construction, there is currently no empirical evidence to verify its theory. It is however unwise to rule out the potential of tessellation planning as many celebrated ideas began small and in theory. It is also conceivable that a drastic change is needed for a paradigm shift in the housing industry as in other industries. When such paradigm shift emerges, we should be well equipped to be able to assess the relationships that develop within that context. Only then can architects be able to truly claim that they have contributed to the creation of the ideal neighbourhood. 


\section{Acknowledgement}

This paper owes tribute to all parties of the supervisory committee for their academic insights as well as industry collaborators for their practical perspectives. It also wishes to acknowledge the conference organisers for creating a unique platform for multiple dialogue opportunities across disciplines.

\section{References}

Aziz, N. A. (2002). The Role of Town Planners in Enhancing the Quality of Life in Klang Valley Urban Development Planning. Unpublished Dissertation, UiTM, Shah Alam.

Aziz, Azhan Abdul \& Ahmad, Abdullah Sani (14-15 November 2009). Home Making in Low- Cost Housing Area. Paper presented at the $1^{\text {st }}$ National Conference on Environment- Behaviour Studies (1nCEBS 2009), FSPU, Universiti TeknologiMARA, ShahAlam, Selangor D.E., Malaysia.

Bajunid, A. F. I. (2011a). Inter-university Online Journal Access. In M. A. M. Nasir (Ed.) (Discussions with PTAR FSPU Librarian on inter-university online journal access, locally and abroad. Deliberated further on inter-library loans and comparative accesses of UiTM's Library services with other local universities. ed.). ShahAlam.

Bajunid, A. F. I. (2011b). Literature Sourcing. In F. A. Jafaar (Ed.) (Discussions with UiTM's PTAR information technology specialist Librarian on online Literature Search methods, and comparative online database analysis between other local Universities. ed.). Shah Alam.

Bajunid, A. F. I. \& Ibrahim, N. (2007, July 1 - 5). Tessellation Planning: Learning from the Hiroshima Experience. Paper presented at the World Housing Congress on Affordable Quality Housing (WHC 2007): Challenges and Issues in the Provision of Shelter for All, Primula Beach Resort, Terengganu, Malaysia.

Charmes, E. (2010). Cul-de-sacs, Superblocks and Environmental Areas as Supports of Residential Territorialization. Journal of Urban Design, 15(3), 357 - 374.

Cohen, L. B. (2011, 21 March). Boolean Searching on the Internet. Internet Tutorials: Your Basic Guide to the Internet Retrieved 23 March, 2011, from http://www. internettutorials.net/boolean.asp

Cozens, P. \& Hillier, D. (2008). The shape of things to come: New urbanism, the grid and the Cul-De-Sac. International Planning Studies, 13(1), 51-73.

Davison, K. K., \& Lawson, C. T. (2006). Do attributes in the physical environment influence children's physical activity? A review of the literature. International Journal of Behavioral Nutrition and Physical Activity, 3.

du Toit, L., Cerin, E., Leslie, E. \& Owen, N. (2007). Does Walking in the Neighbourhood Enhance Local Sociability? Urban Studies, 44(9), 1677-1695.

Ghazali, M. \& Bajunid, A. F. I. (2011). Tessellation Planning and the Small Neighbourhood as an Appropriate Scale for Social Amenities and Engineering Infrastructure to Meet Urban Needs. Paper presented at the 13th International Conference on Humane Habitat (ICHH), Mumbai, India.

Hashim, H. (2005, 11-14 September). Harmonious Community Living in Urban Neighbourhoods: A Case of 
Bajunid, A.F. I., et.al. / Asian Journal of Environmen-Behaviour Studies, ajE-Bs, 2(5) Oct / Dec 2017 (p.85-95)

Central Shah Alam. . Paper presented at the 8th International Conference of the Asian Planning Schools Association (APSA), Grand Plaza Park Royal, Penang, Malaysia.

Hein, C. (2008). Machi. Journal of Urban History, 35(1), 75-107.

Hipp, J. (2010). What is the 'Neighbourhood' in Neighbourhood Satisfaction? Comparing the Effects of Structural Characteristics Measured at the Micro-neighbourhood and Tract Levels. Urban Studies, 47(12), 2517-2536.

Jacobs, J. (1961). The Death and Life of Great American Cities. New York: Random House.

Lawhon, L. L. (2009). The Neighborhood Unit: Physical Design or Physical Determinism? Journal of Planning History, 8(2), 111-132.

Lovejoy, K., Handy, S. \& Mokhtarian, P. (2010). Neighborhood satisfaction in suburban versus traditional environments: An evaluation of contributing characteristics in eight California neighborhoods. Landscape and Urban Planning, 97(1), 37-48.

Mayo, J. M. (1979). Effects of Street Forms on Suburban Neighboring Behavior. Environment and Behavior 11(3), 375397.

Majid, N. A. N. A. (2010). Malaysian Quality of Life. Retrieved 24 March 2011, from EPU, Prime Minister's Department, Malaysia:

Mason, S. G. (2010). Can community design build trust? A comparative study of design factors in Boise, Idaho neighborhoods. Cities, 27(6), 456-465.

Moher, D., Hopewell, S., Schulz, K. F., Montori, V., Gøtzsche, P. C. \& Devereaux, P. J., et al. (2010). CONSORT 2010 Explanation and Elaboration: updated guidelines for reporting parallel group randomised trials. British Medical Journal(BMJ), 340(c869), 1-28.

Mohit, M. A., Ibrahim, M. \& Rashid, Y. R. (2010). Assessment of residential satisfaction in newly designed public low-cost housing in Kuala Lumpur, Malaysia. Habitat International, 34(1), 18-27.

Murry, V. M. M., Berkel, C., Gaylord-Harden, N. K., Copeland-Linder, N. \& Nation, M. (2011). Neighborhood poverty and adolescent development. Journal of Research on Adolescence, 21(1), 114-128.

Nurizan, Y. (1993). Space deficit in low-cost household of Peninsular Malaysia. Kajian Malaysia, 11(1), 56-75.

Othman, S. (2010). Affordances of Cul-de-sac in Urban Neighbourhoods as Play Spaces for Middle Childhood Children. Paper presented at the ASIA / Pasific International Conference on Environment-Behaviour Studies (AicE-Bs 2010), Grand Margherita Hotel, Kucing, Sarawak, Malaysia.

Paquet, C., Cargo, M., Kestens, Y.\& Daniel, M. (2010). Reliability of an instrument for direct observation of urban neighbourhoods. Landscape and Urban Planning, 97(3), 194-201.

Pendola, R. \& Gen, S. (2008). Does "Main Street" Promote Sense of Community? A Comparison of San Francisco Neighborhoods. Environment and Behavior, 40(4), 545-574.

Petticrew, M. \& Roberts, H. (2006). Systematic Reviews in the Social Sciences: A Practical Guide. MA, USA: WileyBlackwell. 
Bajunid, A.F. I., et.al. / Asian Journal of Environmen-Behaviour Studies, ajE-Bs, 2(5) Oct / Dec 2017 (p.85-95)

Schulz, K. F., Altman, D. G. \& Moher, D. (2010). CONSORT 2010 Statement: updated guidelines for reporting parallelgroup randomised trials. Annals of InternalMedicine, 152(11), 1-8.

Shepley, M. M., Harris, D. D. \& White, R. (2008). Open-Bay and Single-Family Room Neonatal Intensive Care Units. Environment and Behavior, 40(2), 249-268.

Southworth, M. \& Ben-Joseph, E. (1995). Street Standards and The Shaping of Surburbia. Journal of The American Planning Association, Vol. 61(1), 65-81.

Southworth, M. \& Ben-Joseph, E. (1997). Streets and the Shaping of Towns and Cities. New York: McGraw-Hill.

Southworth, M. \& Owens, P. M. (1993). The evolving metropolis: studies of community, neighborhood, and street form at the urban edge. Journal - American Planning Association, 59(3), 271-287.

Veitch, J., Salmon, J. \& Ball, K. (2010). Individual, social and physical environmental correlates of children's active free-play:Across-sectionalstudy. International Journal of Behavioral Nutrition and Physical Activity,

Zakaria, R. \& Yang, J. (2004). Smart and sustainable inhabitation in residential-industrial neighbourhood. Paper presented at the Engineering Management Conference, 2004. Proceedings. 2004 IEEE International. 